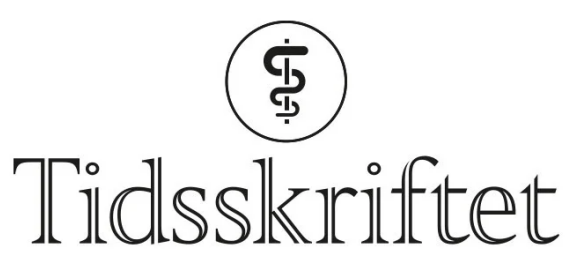

DEN NORSKE LEGEFORENING

\title{
En mann i 6o-årene med dyspné etter immunterapi
}

NOE Å LARE AV

\section{HARALD BULL RAGNUM}

hbragnum@gmail.com

Avdeling for blod- og kreftsykdommer

Sykehuset Telemark

Harald Bull Ragnum er lege i spesialisering i onkologi.

Forfatteren har fylt ut ICMJE-skjemaet og oppgir ingen interessekonflikter.

\section{ALESSANDRO MÜLLER DE BORTOLI}

Department of Cardiology

Oslo University Hospital, Rikshospitalet

Alessandro Müller De Bortoli, specialty registrar in cardiology.

The author has completed the ICMJE form and declares no conflicts of interest.

\section{AHMED ELSAIS}

Nevrologisk avdeling

Oslo universitetssykehus, Rikshospitalet

Ahmed Elsais er dr.med., spesialist i nevrologi og overlege.

Forfatteren har fylt ut ICMJE-skjemaet og oppgir ingen interessekonflikter.

\section{KRISTIAN BERNHARD NILSEN}

Seksjon for klinisk nevrofysiologi

Nevrologisk avdeling

Oslo universitetssykehus

Kristian Bernhard Nilsen er spesialist i klinisk nevrofysiologi, seniorforsker og seksjonsleder.

Forfatteren har fylt ut ICMJE-skjemaet og oppgir ingen interessekonflikter.

\section{CLARA HAMMARSTRÖM}

Department of Pathology Oslo University Hospital, Rikshospitalet

Clara Hammarström, specialist in pathology and senior consultant.

The author has completed the ICMJE form and declares no conflicts of interest.

\section{MARTA NYAKAS}

Utprøvningsenheten

Oslo universitetssykehus, Radiumhospitalet

Marta Nyakas er spesialist i onkologi og har ansvar for melanomstudier ved Utprøvningsenheten. Hun er spesielt engasjert i bivirkninger knyttet til immunterapi. 


\section{Immunterapi har bedret prognosen ved mange kreftsykdommer, men bivirkningene kan være alvorlige, noe denne kasuistikken illustrerer. De er fundamentalt forskjellige fra bivirkninger av cytostatika og kan oppstå fra alle organsystemer. Kunnskap om disse bivirkningene er derfor viktig på tvers av medisinske spesialiteter.}

En mann i 6o-årene fikk diagnostisert nyrekreft med metastaser til lungene etter to måneder med feber, hoste og tresifret CRP-verdi, uten respons på peroral antibiotikabehandling. Han hadde tidligere vart igjennom et langvarig intensivopphold pga. spondylodiskitt og hadde vitiligo, men var ellers frisk. Han ble grunnet beskjeden metastasebyrde anbefalt nefrektomi, der histologien viste klarcellet nyrekarsinom. Pasientens allmenntilstand normaliserte seg etter fjerning av nyren. CT thorax, abdomen og bekken etter operasjonen viste spontan tilbakegang av lungemetastaser, men samtidig sentrale lungeembolier, og han fikk antikoagulasjonsbehandling med lavmolekylcert heparin. Ved kontroll fem måneder etter operasjonen hadde det imidlertid tilkommet tumormasser mellom lever og kolon. Lungemetastasene hadde vokst, og det var indikasjon for systemisk behandling. Pasienten hadde nå ingen avvikende blodprøver, og allmenntilstanden var helt upåfallende. Han ble anbefalt immunterapi i form av ipilimumab og nivolumab.

Medikamentell behandling av nyrekreft skiller seg fra mange andre kreftsykdommer, siden cytostatika har liten plass. En viktig behandlingsform er immunterapi, der man bruker antistoffer for å hemme immunforsvarets bremser (1). Disse medikamentene kalles ofte sjekkpunkthemmere og gis som infusjoner med faste intervaller. Ipilimumab hemmer overflatemolekylet cytotoksisk T-lymfocytt antigen-4 (CTLA-4), mens nivolumab hemmer overflatemolekylet programmert celledød-1 (PD-1)(1). Kombinasjonsbehandling med ipilimumab og nivolumab mot metastatisk nyrekreft ble godkjent i Beslutningsforum primo 2020 ( $\underline{2})$ og er anbefalt i europeiske retningslinjer (3). De norske retningslinjene for behandling av metastatisk nyrekreft er imidlertid ikke oppdatert siden 2015 (4).). Formålet med immunterapi er å øke immunresponsen rettet mot kreftsvulsten, men behandlingen gir samtidig risiko for autoimmune reaksjoner i normalt vev. Ved kombinasjon av ipilimumab og nivolumab er denne risikoen spesielt høy (프).

Det ble opprettet åpen retur til lokal kreftavdeling, og pasienten ble satt opp til ukentlig blodprøvekontroll $i$ starten. Ved kontroll etter fjorten dager hadde han stigende leverprøver, med aspartataminotransferase (ASAT) 224 U/L (15-45), alaninaminotransferase (ALAT) 159 U/L (10-70), bilirubin $7 \mu \mathrm{mol} / \mathrm{L}((5)-25)$, alkalisk fosfatase (ALP) $136 \mathrm{U} / \mathrm{L}$ (35-105) og gammaglutamyltransferase (gamma-GT) $188 \mathrm{U} / \mathrm{L}\left(15^{-115}\right)$.

Differensialdiagnosene inkluderte hepatitt pga. immunterapi, men $i$ henhold til retningslinjer var nivået ikke høyt nok til at man skulle starte med steroider (5). Det kom også frem at pasienten hadde brukt mer paracetamol enn anbefalt de siste tre dagene, noe som kunne bidra til blodprøvebildet. Alkoholforbruket var moderat. Negative antistofftester mot hepatitt B og C var avklart før oppstart av immunterapi. Han ble satt opp til kontroll to dager senere, der man så en ytterligere stigning $i$ transaminaser, med ASAT 472 U/L og ALAT 291 U/L samt uendrete staseparametre. Tilstanden ble tolket som immunterapiutløst hepatitt grad 3 (5), og prednisolon i dose $1 \mathrm{mg} / \mathrm{kg} / \mathrm{døgn}$ per os ble startet. Pasienten hadde i tillegg fått hoste og lett tungpustethet, og fastlegen hadde skrevet ut doksysyklin under mistanke om luftveisinfeksjon. Han stod fortsatt på behandlingsdoser med lavmolekylcrt heparin, og nytilkomne lungeembolier var lite sannsynlig.

Ved alvorlige bivirkninger av immunterapi er steroider i høydose og eventuelt andre immunsuppressiver en sentral del av behandlingen (5). Det er imidlertid viktig å overveie differensialdiagnoser, som i dette tilfellet inkluderte overforbruk av paracetamol. 
To dager senere, 18 dager etter immunterapien, kontaktet pasienten lokalsykehuset pga. økende tungpustethet. Han ble meldt til øyeblikkelig hjelp-innleggelse. Han hadde ikke brystsmerter, var våken, klar og orientert, men engstelig. Blodtrykket var 144/95 mm Hg, pulsen 111 per minutt og regelmessig, respirasjonsfrekvensen 19 per minutt, saturasjonen 93 \% på romluft og temperaturen $37,4^{\circ} \mathrm{C}$ rektalt. Arteriell blodgass viste $\mathrm{pH} 7,38$ (7,35-7,44), $\mathrm{pO}_{2}$ 8,83 $\mathrm{kPa}(10,0-14,0), \mathrm{pCO}_{2} 4,87 \mathrm{kPa}$ $(4,7-6, \mathrm{o}), \mathrm{HCO}_{3}-21,3 \mathrm{mmol} / \mathrm{L}(22-26)$, baseoverskudd $-3,8 \mathrm{mmol} / \mathrm{L}$ (-3,o til 3,o) og laktat 1,29 $\mathrm{mmol} / \mathrm{L}$ $(0,5-2,5)$.

EKG viste sinustakykardi med frekvens 110 per minutt med nyoppstått venstre fremre hemiblokk og høyre grenblokk. Det var normal PQ-tid og korrigert QT-tid på 460 millisekunder. Blodprøver avdekket økende transaminaser, med ASAT $503 \mathrm{U} / L$, ALAT $443 \mathrm{U} / \mathrm{L}$, stabile staseparametre, lett forhøyet D-dimer på 1,o mg/L (<o,7), forhøyet NT-proBNP på $733 \mathrm{ng} / \mathrm{L}(<250)$, samt markant forhøyet troponin I på $14834 \mathrm{ng} / \mathrm{L}(<47)$, som var forenelig med myokardaffeksjon. Ekkokardiografi viste normal ejeksjonsfraksjon uten områder med hypokinesi eller andre avvik. CT thorax med lungeemboliprotokoll viste normal torakalaorta, ingen lungeembolier og ikke patologi $i$ lungeparenkymet ut over små metastaser.

Akutt koronarsyndrom og myokarditt var mulige differensialdiagnoser. Pasienten hadde ikke brystsmerter, og ekkokardiografi viste normale funn uten områder med hypokinesi. Han hadde ingen tidligere hjertesykdom, og foruten alder hadde han heller ikke kjente risikofaktorer. Sannsynligheten for akutt koronarsyndrom ble ansett som lav. Sykehistorien og kliniske funn gav mistanke om akutt myokarditt.

Han ble overført til universitetssykehus for videre utredning samme dag. Ved ankomst var pasienten respiratorisk og hemodynamisk stabil. Ekkokardiografi viste normalt stor venstre ventrikkel med hyperdynamisk funksjon. Få timer senere utviklet pasienten imidlertid aberrant overledet atrieflimmer med frekvens 177 per minutt (figur 1a). Intravenøs injeksjon med $5 \mathrm{mg}$ metoprolol gav kontroll over takykardien, men medførte markert sinusbradykardi, trifasikulcert blokk og innslag av totalt AV-blokk med pauser på opptil 4 sekunder (figur 1b). En transvenøs, temporcer pacemaker ble derfor implantert $i$ høyre ventrikkel via vena jugularis interna. Pacemakerens basalfrekvens ble satt til 40 per minutt. 


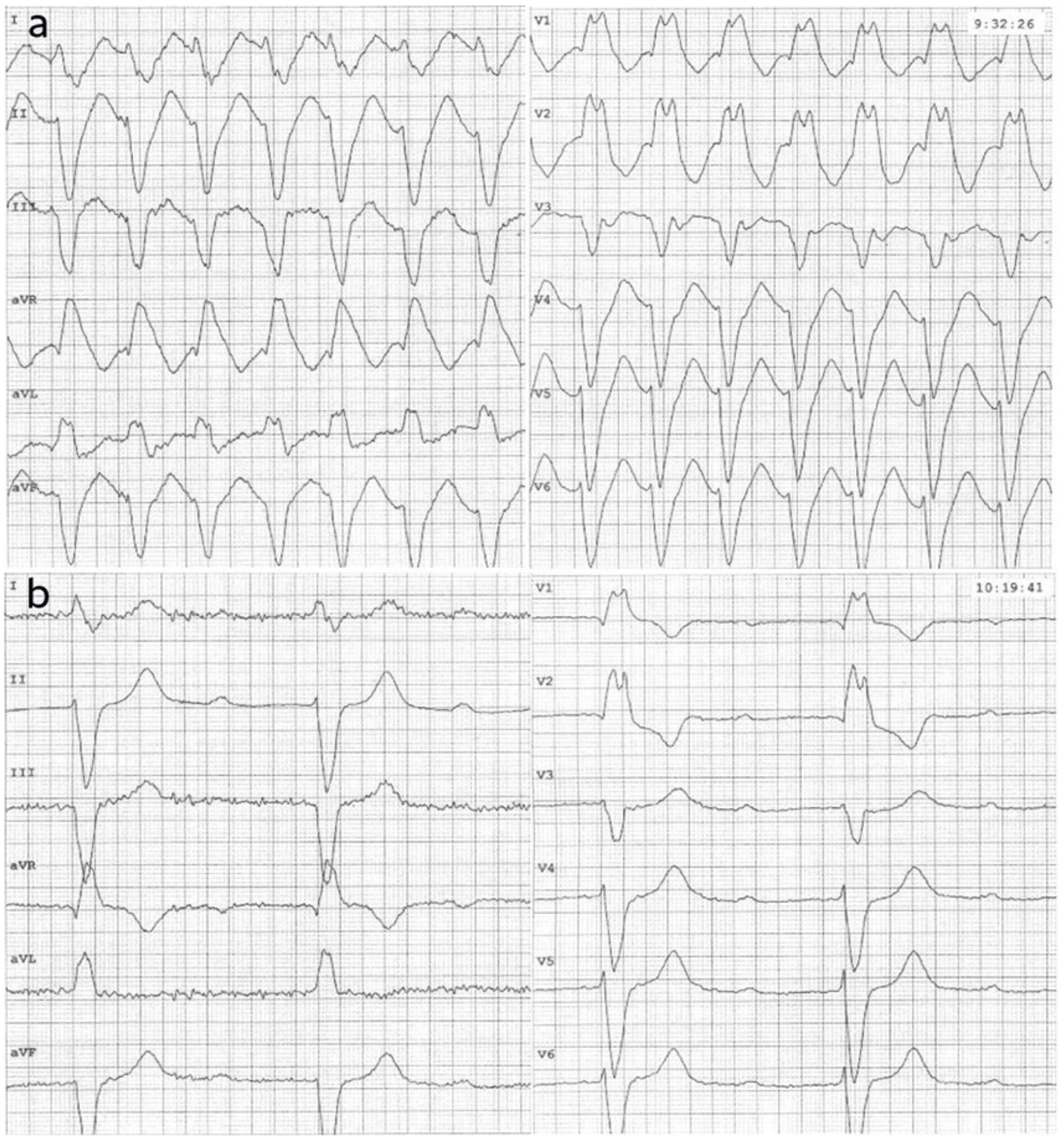

Figur 1 EKG tatt med 50 minutters mellomrom som viser pasientens fluktuerende hjerterytme. Papirhastighet 50 mm/s. Tidspunktene er angitt i øvre, høyre hjørne. a) Bredkomplekset, uregelmessig takykardi med lik QRS-konfigurasjon som ved sinusrytme. Frekvens 177 per minutt. Rytmen ble oppfattet som rask atrieflimmer, aberrant overledet. b) Sinusrytme med frekvens 55 per minutt og trifasikulært blokk. Det er betydelig forlenget PQ-tid på nesten 500 millisekunder, venstre fremre hemiblokk og høyre grenblokk. Dag 3 etter innleggelsen ble pasienten økende dyspneisk. Arteriell blodgass viste alvorlig respiratorisk acidose med $\mathrm{CO}_{2}$-retensjon, men adekvat oksygenering $\left(\mathrm{pH} 7,12, \mathrm{pO}_{2}\right.$ 16,1 $\mathrm{kPa}, \mathrm{pCO}_{2}$ 12,2 $\mathrm{kPa}, \mathrm{HCO}_{3} 29,5 \mathrm{mmol} / \mathrm{L}$, baseoverskudd o mmol/L og laktat 1,1 $\left.\mathrm{mmol} / \mathrm{L}\right)$. Ikke-invasiv ventilasjonsstøtte i form av BiPAP ble igangsatt samme dag med god effekt. Dag 4 ble det utført koronarangiografi, uten tegn til stenoser. MR hjerte var kontraindisert grunnet pacemaker, og som alternativ ble det gjort høyresidig hjertekateterisering med biopsitaking. Histologisk analyse viste flekkvis lymfocytcer betennelse og myocyttskade forenelig med akutt myokarditt (figur 2). 


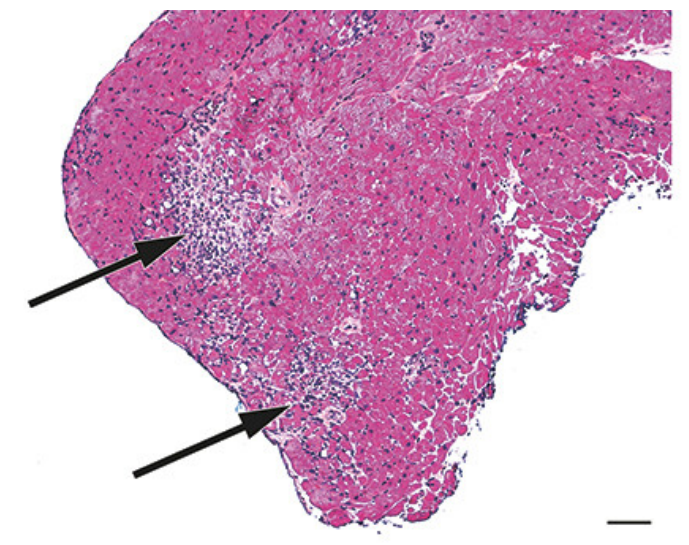

Figur 2 Hematoksylin-eosin- og safranfarget snitt fra hjertebiopsien. a) Her ses flekkvise betennelsesinfiltrater (piler) i myokard. Forstørrelse ×10o, målestokk $100 \mu \mathrm{m}$. b) I områder med betennelse ses myocyttskade med nekrotiske og vakuoliserte muskelfibre (piler) til dels infiltrert av lymfocytter, samt fokalt tap av muskelfibre $\left({ }^{*}\right)$. Forstørrelse $\times 400$, målestokk $25 \mu \mathrm{m}$.

Myokarditt er en inflammatorisk tilstand med flere årsaker, der virale infeksjoner er den vanligste. Histologisk ser man betennelsesinfiltrater med eller uten nekrose av hjertemuskelceller. Presentasjonsformen varierer fra subklinisk sykdom til kardiogent sjokk (ㅁ). Myokarditt ved behandling med immunterapi er beskrevet som en sjelden, men alvorlig tilstand. I en multisenter registerstudie fant man en forekomst på ca. 1 \% blant pasientene (7.). Behandlingen består av høydose steroider, kombinert med andre immunsuppressiver. Prognosen ved myokarditt forårsaket av immunterapi er alvorlig, med rapportert mortalitet rundt $50 \%(\underline{8})$.

Pasienten ble behandlet i totalt seks døgn med prednisolon $1 \mathrm{mg} / \mathrm{kg} / \mathrm{d} ø g n$, to døgn før og fire døgn etter innleggelse. Han hadde en betydelig klinisk forverring i løpet av disse dagene. Til tross for biokjemisk bedring med vedvarende lav CRP-verdi og fallende verdier av transaminaser, troponin og proBNP var pasienten respiratorisk og sirkulatorisk ustabil. Perioder med apné alternerte med takypné og kavete respirasjon. Hjerterytmen vekslet mellom atrieflimmer med frekvens opp mot 150 per minutt til sinusrytme med totalt AV-blokk og nodal erstatningsrytme med frekvens 50 per minutt. Han hadde svingende blodtrykk med verdier fra 71/48 mm Hg til 188/79 mm Hg i løpet av samme døgn, som resulterte $i$ henholdsvis svimmelhet og bevissthetstap og hypertensivt lungeødem. Dag 5 etter innleggelse ble CT thorax gjentatt, uten holdepunkt for infiltrater eller embolier. På grunn av mistanke om behandlingssvikt ble immunsuppresjonen etter en tverrfaglig vurdering eskalert til metylprednisolon 1 ooo mg intravenøst daglig, med tillegg av mykofenolatmofetil 1 ooo mg morgen og kveld. To dager senere la man også til takrolimus $2 \mathrm{mg}$ morgen og kveld.

Pasientens tilstand kunne ikke forklares av myokarditt alene. Det var ikke lungeembolier eller infiltrater på CT thorax. Det var klinisk forverring til tross for fallende transaminaseog troponinverdier. Flere nevrologiske tilstander som polynevropati, myasthenia gravis, Guillain-Barrés syndrom, encefalitt og aseptisk meningitt er beskrevet ved behandling med immunterapi (5). Det er også rapportert autoimmun, autonom ganglionopati med forstyrrelser i det autonome nervesystemet og hypotensjon etter behandling med ipilimumab og nivolumab (9.). Man mistenkte at det kliniske bildet kunne skyldes en autonom dysfunksjon med påvirkning av respirasjons- og blodtrykksregulering. Nevrologisk tilsyn ble derfor rekvirert.

Den nevrologiske undersøkelsen ble begrenset av pasientens dyspné. Man fant oftalmoplegi med innskrenket sideblikk og diplopi som ved bilateral abdusensparese samt ataktiske øyebevegelser. Det var pareser i ekstremitetene, mest uttalt $i$ underekstremitetene, og ncermest global arefleksi. Nevrografi viste lave amplituder i overekstremitetene, spesielt for sensoriske nerver, og manglende svar i underekstremitetene. Det var imidlertid markert økt distal latenstid i motoriske nerver, med moderat redusert ledningshastighet og til dels betydelig forlengete F-responser. Elektromyografi 
$(E M G)$ viste ingen spontanaktivitet, men tydelig redusert rekruttering $i$ underekstremitetene. Fravcer av motorisk respons i underekstremitetene ble oppfattet som uttalt distalt konduksjonsblokk, og dette samsvarte med de kliniske funnene med pareser og arefleksi.

Kombinasjonen av disse funnene er uvanlig og ble tolket som en immunologisk betinget akutt polynevropati. Flere differensialdiagnoser ble vurdert, som primær autoimmun polyradikulitt (Guillain-Barrés syndrom/Miller-Fishers syndrom) med eller uten Bickerstaffs hjernestammeencefalitt, eller paraneoplastisk polynevropati med hjernenerveaffeksjon.

Spinalpunksjon var ikke mulig grunnet full antikoagulasjon, og temporcer pacemaker vanskeliggjorde MR caput. Det ble iverksatt behandling med intravenøst immunglobulin i påvente av svar på gangliosid- og nevronantistoffer, som i ettertid viste seg å vcere negative. Etter tre dagers behandling uten bedring forberedte man plasmaferese samt behandling med rituksimab som siste utvei.

Pasienten fallerte imidlertid før dette kunne settes i gang. Han hadde fallende blodtrykk til $60 / 40 \mathrm{~mm}$ Hg og bradykardi med frekvens 50 per minutt. Det ble forsøkt å øke pacemakerfrekvensen, uten positiv effekt på blodtrykket. Ekkokardiografi viste uendret status fra tidligere, med velkontraherende venstre og høyre ventrikkel uten regionale kontraksjonsforstyrrelser eller perikardvceske. Man gav adrenalinbolus med initial effekt, etterfulgt av innslag av atrieflimmer med nytt hypotensivt sjokk. Maksimaldoser med noradrenalin var ikke tilstrekkelig for å holde et adekvat blodtrykk, svarende til en uttalt autonom dysregulering med vasoplegi. Anestesilege ble tilkalt for vurdering. Pasienten hadde vart avhengig av BiPAP i flere dager. Han hadde respirasjonsfrekvens på 22 per minutt med innstilt minstefrekvens på 8 per minutt på apparatet. Ved fors $ø k$ på reduksjon av trykkstøtten fra $10 \mathrm{~cm}$ til $2 \mathrm{~cm} \mathrm{H}_{2} \mathrm{O}$ i diagnostisk hensikt falt tidevolumet fra $600 \mathrm{~mL}$ til $150 \mathrm{~mL}$.

Pasienten hadde dyspné, og etter overflytting til universitetssykehuset fikk han hyperkapni. Sentralnevrologisk påvirkning som medførte hypoventilasjon var én av hypotesene, men adekvat respirasjonsfrekvens talte mot dette. Imidlertid var han avhengig av trykkstøtte for å holde et adekvat tidevolum. Perifer nevromuskulær sykdom med affeksjon av nervus phrenicus er en mulig forklaring.

Pasientens tilstand var kritisk. Han uttrykte imidlertid gjentatte ganger at han ikke ønsket respiratorbehandling. Det ble i samråd med pårørende besluttet å ikke trappe opp behandlingsintensiteten, men heller fokusere på ren palliasjon ved forverring. Pasienten ble dårligere påfølgende natt, og døden inntraff 11 dager etter innleggelse, 29 dager etter behandling med immunterapi.

\section{Diskusjon}

Immunterapi har bedret prognosen ved flere kreftsykdommer og får stadig nye indikasjoner. Imidlertid gir immunterapi utfordringer med andre bivirkninger enn vi tradisjonelt er vant til ved kreftbehandling. Dette er tidligere beskrevet i Tidsskriftet (10 $)$, der en pasient fikk diabetes mellitus etter behandling med nivolumab. Vår kasuistikk viser et svært alvorlig og dramatisk forløp etter kun én kur med ipilimumab og nivolumab.

Håndtering av immunterapibivirkninger har blitt en viktig del av hverdagsonkologien. Bivirkningene kan komme etter én kur, senere under behandlingen eller opptil ett år etter avsluttet behandling (5). Pasientene kan komme til akuttmottaket, hos fastlegen eller på legevakten med alt fra røde øyne, utslett, tungpustethet, diaré, slapphet eller hodepine. De kan få autoimmune reaksjoner i alle kroppens organer. Hvis anamneseopptaket avdekker at pasienten mottar eller tidligere har mottatt immunterapi, må en reaksjon på denne være blant differensialdiagnosene. Rask kontakt med nærmeste kreftavdeling, der man vurderer oppstart av steroider i høye doser og annen immunsuppressiv behandling, kan redde liv og organfunksjon. Det er viktig at pasientene er godt informert om farene ved immunterapi og hvilke symptomer som skal lede til kontakt med nærmeste kreftavdeling. I de fleste tilfellene er bivirkningene mindre alvorlige enn i denne kasuistikken, og behandlingen kan da ofte fortsette etter en kur med steroider. 
Vår pasient hadde leverenzymutfall forenelig med hepatitt samt arytmi, forhøyet troponinverdi og betennelsesforandringer i hjertebiopsien forenelig med myokarditt. Imidlertid ble de nevrologiske symptomene mest fremtredende etter hvert, der undersøkelser viste et komplekst og uavklart bilde med sensorimotoriske, perifere nerveutfall samt affeksjon av hjernenerver og antatt autonom dysregulering. Pasienten hadde også vitiligo. Pasienter med alvorlige autoimmune sykdommer har ofte vært ekskludert fra studier med immunterapi (1ㅡ), men i Motzer og medarbeideres studie på metastatisk nyrekreft og immunterapi var vitiligo tatt med (1). En litteraturgjennomgang fra 2020 antyder at pasienter med autoimmun sykdom kan oppleve en forverring av denne under immunterapi, uten overhyppighet av andre autoimmune reaksjoner (11).

Pasienter som mottar immunterapi må følges tett, spesielt i starten. Det er typisk at de mest alvorlige reaksjonene kommer raskt etter oppstart, som hos vår pasient (프). Han ble rutinemessig fulgt opp med blodprøver og telefonkonsultasjoner. Man mistenkte immunterapiutløst hepatitt og startet derfor med steroider. Han hadde ved oppstart av steroider også dyspné. Siden han hadde mulig affeksjon av to organsystemer og ASAT-verdi over $400 \mathrm{U} / \mathrm{L}$, kan det argumenteres for at han burde vært innlagt tidligere for bredere diagnostikk og høyere doser med steroider (5). Til tross for stadig forverring av situasjonen stod han senere i forløpet på samme dose steroider i seks døgn uten at øvrige immunsuppressiver ble lagt til. Steroiddosen burde vært økt og øvrige immunsuppressiver lagt til på et tidligere tidspunkt.

Det er verdt å merke seg at pasienter med tilsvarende behandling har 47 \% sannsynlighet for å få en alvorlig bivirkning i løpet av behandlingsperioden, men at et fatalt utfall heldigvis sjelden forekommer (13). Det er laget flere verktøy for å vurdere alvorlighetsgraden av bivirkninger og for å gi råd om passende tiltak i akuttsituasjonen. Vi nevner spesielt Oslo universitetssykehus sin elektroniske håndbok (14.). Denne bygger på flere internasjonale retningslinjer, blant annet utgitt av American Society of Clinical Oncology (15), National Comprehensive Cancer Network (1흐) og European Society for Medical Oncology (5).

Pasientens pårørende har gitt tillatelse til at artikkelen blir publisert. Vi takker Tormod Helås for gjennomlesing av manuskriptet og gode tilbakemeldinger. Artikkelen er fagfellevurdert.

LITTERATUR

1. Motzer RJ, Tannir NM, McDermott DF et al. Nivolumab plus ipilimumab versus sunitinib in advanced renal-cell carcinoma. N Engl J Med 2018; 378: 1277-9o. [PubMed][CrossRef]

2. Nye Metoder. Ipilimumab (Yervoy) / Nivolumab (Opdivo) - Indikasjon IV.

https://nyemetoder.no/metoder/ipilimumab-yervoy-nivolumab-opdivo-indikasjon-iv Lest 4.6.2021.

3. Ljungberg B, Albiges L, Bedke J et al. European Association of Urology guidelines: Renal cell carcinoma. https://uroweb.org/guideline/renal-cell-carcinoma/ Lest 4.6.2021.

4. Helsedirektoratet. Nasjonale retningslinjer for diagnostikk, behandling og oppfølging av nyrecellekreft. 8 Behandling av metastaserende sykdom og livsforlengende og palliativ behandling. https://www.helsebiblioteket.no/retningslinjer/nyrekreft/behandling-av-metastaserende Lest 4.6.2021.

5. Haanen JBAG, Carbonnel F, Robert $C$ et al. Management of toxicities from immunotherapy: ESMO Clinical Practice Guidelines for diagnosis, treatment and follow-up. Ann Oncol 2017; 28 (suppl 4): iv119-42. [PubMed][CrossRef]

6. Cooper LT. Myocarditis. N Engl J Med 2009;36o: 1526-38. [PubMed][CrossRef]

7. Mahmood SS, Fradley MG, Cohen JV et al. Myocarditis in patients treated with immune checkpoint inhibitors. J Am Coll Cardiol 2018; 71: 1755-64. [PubMed][CrossRef]

8. Salem JE, Manouchehri A, Moey M et al. Cardiovascular toxicities associated with immune checkpoint inhibitors: an observational, retrospective, pharmacovigilance study. Lancet Oncol 2018; 19:1579-89. [PubMed][CrossRef] 
9. Gao CA, Weber UM, Peixoto AJ et al. Seronegative autoimmune autonomic ganglionopathy from dual immune checkpoint inhibition in a patient with metastatic melanoma. J Immunother Cancer 2019; 7: 262. [PubMed][CrossRef]

10. Skorpen PK, Margull J. Diabetisk ketoacidose etter immunterapi mot lungekreft. Tidsskr Nor Legeforen 2019; 139. doi: 10.4045/tidsskr.18.0597. [PubMed][CrossRef]

11. Coureau M, Meert AP, Berghmans T et al. Efficacy and toxicity of immune-Checkpoint inhibitors in patients with preexisting autoimmune disorders. Front Med (Lausanne) 2020; 7: 137. [PubMed] [CrossRef]

12. Wang DY, Salem JE, Cohen JV et al. Fatal toxic effects associated with immune checkpoint inhibitors: A systematic review and meta-analysis. JAMA Oncol 2018; 4:1721-8. [PubMed][CrossRef]

13. Motzer RJ, Rini BI, McDermott DF et al. Nivolumab plus ipilimumab versus sunitinib in first-line treatment for advanced renal cell carcinoma: extended follow-up of efficacy and safety results from a randomised, controlled, phase 3 trial. Lancet Oncol 2019; 20: 1370-85. [PubMed][CrossRef]

14. Oslo universitetssykehus - eHåndbok. Immunterapi-bivirkninger - akuttmedisinsk prosedyre. https://ehandboken.ous-hf.no/document/135421 Lest 4.6.2021.

15. Brahmer JR, Lacchetti C, Schneider BJ et al. Management of immune-related adverse events in patients treated with immune checkpoint inhibitor therapy: American Society of Clinical Oncology Clinical practice guideline. J Clin Oncol 2018;36: 1714-68. [PubMed][CrossRef]

16. Thompson JA, Schneider BJ, Brahmer J et al. NCCN Guidelines Insights: Management of immunotherapy-related toxicities, version 1.2020. J Natl Compr Canc Netw 2020; 18: 230-41. [PubMed] [CrossRef]

Publisert:3. september 2021. Tidsskr Nor Legeforen. DOI: 10.4045/tidsskr.21.0139

Mottatt 18.2.2021, første revisjon innsendt 8.6.2021, godkjent 15.6.2021.

Publisert under åpen tilgang CC BY-ND. Lastet ned fra tidsskriftet.no 26. april 2023. 